\title{
Dociekania
}

\section{Pamięć nieumarła. Czytając Kazimierza Wykę w Polsce roku 2016}

\author{
Joanna Tokarska-Bakir
}

TEKSTY DRUGIE 2016, NR 6, S. 106-121

DOI: 10.18318/td.2016.6.8

ak zmienia się dziś relacja pomiędzy historią i pamięcią? W jakiej konfiguracji pojawiają się w historii zjawiska „fałszywej pamięci” i „fałszywego świadka”? Kiedy historia mówiona zatraca swoją emancypacyjną funkcję, upodobniając się do politycznego brzuchomówstwa? W jakich warunkach pamięć jednostkowa podporządkowuje się zbiorowej, godząc się na ubywanie kolejnych reprezentacji świata społecznego? Czy w obszarze pamięci istnieją odpowiedniki walking dead, nieumarłych, i jak można im zaradzić? Oto garść pytań, które towarzyszą mi przy tegorocznej lekturze Życia na niby.

\section{Wyka o Goebbelsie}

W tekście Goebbels, Hitler i Kato pisanym po ataku Rzeszy na ZSRR autor dziwi się skuteczności goebbelsowskiej propagandy:

Wystarczyło rzucić pęk niby twierdzeń i niby dokumentów, aby cały naród [mowa o narodzie niemieckim] nową, o nieprzejrzanej doniosłości sytuację
Joanna Tokarska-

-Bakir (ur. 1958)

- prof. dr hab., antropolożka kultury i religioznawczyni, Instytut Slawistyki PAN. Zajmuje się antropologią historyczną. Autorka m.in. Légendes du sang, Paris 2015 (wyd. pol. Legendy o krwi. Antropologia przesqdu); Okrzyki pogromowe. Szkice z antropologii historycznej Polski lat 1939-1946 (2012), Społeczny portret pogromu kieleckiego, 2 tomy ( $w$ druku). 
przyjął niczym dodatkową kartę odzieżową. Ten zdumiewający przeskok, to niesamowite przestawienie od milczenia i pomruków przyjaźni do skoku w gardło i wrzasku histerycznej wrogości! Prawda, która rozpoczyna się od chwili nowego twierdzenia, nie sięga wstecz. I niknie za następnym nowym twierdzeniem. ${ }^{1}$

Tekst Wyki jest analizą epistemologii propagandy, o ponad dekadę wyprzedzającą Prawdę i politykę Hannah Arendt. Wyolbrzymienie lub degradacja faktów, pisze autor, intencjonalna hipertrofia znaczenia włożona w fakt drugorzędny rozsadza go. „Tworzy się całości i związki przyczynowe tam, gdzie one nie istnieją. Przerywa się natomiast i wyodrębnia te zależności, które naprawdę istnieją"2. Fakty kreowane przez propagandę nie wytwarzają własnego cienia. Nie można ich obejrzeć od innej strony, oświetlone inaczej - znikają.

Demoniczne jest nie tylko to, że propaganda stwarza fakty, mówi dalej Wyka. Jeszcze gorsze, że

osobnik, społeczeństwo, naród, któremu stale i konsekwentnie usuwa się z pamięci pewne zjawiska, a narzuca drugie, dochodzi w końcu, prawem znużenia psychicznego, do przekonania, iż fakty usuwane nie egzystują i nigdy nie egzystowały. Na odwrót, prawem nawyku i oswojenia, fakty wmuszone i podkreślane, poczynają działać jak rzeczywiste. Należy się obawiać, że po przegranej wojnie społeczeństwo niemieckie nadal nie będzie wierzyć w obozy koncentracyjne, a natomiast będzie wierzyć w swoją misję obrońców Europy. ${ }^{3}$

Aby wyjaśnić ten efekt - jest rok 1942 - Wyka przywołuje starą teorię Gustave'a Le Bona, dowodząc, jak pojętnym jego uczniem był autor Mein Kampf. I choć z dzisiejszej perspektywy lepiej niż Le Bon wyjaśniłby to Kurt Theweleit, warto przytoczyć za Wyką ilustrujący tę zależność cytat z Hitlera: „Zdolność pojmowania wielkich mas jest bardzo ograniczona, rozum niewielki, ale za to zdolność zapominania duża"; zadanie propagandy, a także sztuki, polega więc zawsze na tym, aby wytwarzały „powszechne przekonanie

1 K. Wyka, Goebbels, Hitler i Kato, w: tegoż Życie na niby, Universitas, Kraków 2010 (dalej: ŻnN), s. 166 .

2 ŻnN, s. 184.

$3 \dot{Z n N}$, s. 178 . 
o prawdziwości danego faktu, o konieczności danego postępku”, niezależnie od tego, czy fakt był prawdziwy, a postępek konieczny.

\section{Theweleit o języku propagandy}

Tak wódz Niemców uzasadniał konieczność wytwarzania rzeczywistości, w czym jego krytyk, Kurt Theweleit, upatruje istoty faszyzmu ${ }^{5}$. W ujęciu Theweleita faszyzm nie opiera się na uwiedzeniu czy błędnym rozpoznaniu, ale właśnie na produkcji rzeczywistości, dzięki czemu to, co jest, zostaje wyparte przez dobrze uzasadnioną nicość - to, czego nie ma, ale co stanowi przedmiot pragnienia. Środkiem produkcji staje się faszystowska mowa, która sprawia, że wchłaniane przez język cząstki świata tracą swoje właściwości.

Poza nielicznymi badaczami w latach 70. we Francji niemal nikt nie zajmował się językiem faszyzmu. Klasa średnia nie dociekała znaczeń w nim zawartych, aby ukryć swoje własne uwikłanie, natomiast komuniści unieważniali go „z gestem rzeźbionego stalinowskiego herosa, który za chwilę zrobi z tym wszystkim porządek" (82). W rezultacie „żałosna gładkość frazesu", której w „cyklopowatych konstrukcjach" faszyzmu dopatrywał się Walter Benjamin (617), sama stała się gładkim frazesem.

Mowa faszystowska jest groźna dlatego, że odwrót od rzeczywistości można ogłosić w każdym czasie i w każdym miejscu. Wystarczy zainicjować „język okupacji" (219), który z przedstawianymi obiektami nie wchodzi w stosunki pozwalające je sobie wyobrazić (99). Podobny język nie chce nic wiedzieć o swoim przedmiocie. Z wielości informacji wyciąga bardzo niewiele, $\mathrm{w}$ dodatku „zawsze to samo, tak że wybór ten jawi się w końcu jako pewien przymus" (100). Wygląda to tak, jakby ten język miał jednego fikcyjnego autora, który spisuje protokół zawłaszczania rzeczywistości.

Przemoc, której dopuszcza się ów język i o której chętnie opowiada, nigdy nie jawi się jako przedmiot wyboru czy skłonności, lecz jako moralny i patriotyczny obowiązek. Theweleit sprzeciwia się, by stojący za ową przemocą mechanizm urojenia określać mianem projekcji. „Tak zwana projekcja nie sprowadza się do urojeń. Relacja między rzeczywistym obiektem agresji $i$ atakowanym obiektem zastępczym nie jest przypadkowa" (162). Także teoria kozła ofiarnego stanowi, zdaniem Theweleita, uproszczenie w wyjaśnianiu

4 A. Hitler Mein Kampf, cyt. za: ŻnN, s. 191.

5 K. Theweleit Męskie fantazje, przeł. M. Falkowski, M. Herer (dalej: MF), s. 100. Numery stron w nawiasach oznaczają kolejne cytaty z tej książki. 
adresu faszystowskiej agresji. Nazywa ją raczej „halucynacyjnym zastąpieniem obiektu". Ofiara tego zastąpienia wykazuje pewne podobieństwo do obiektu wyjściowego, ale ciosy, które zbiera, odnoszą się faktycznie do osobistej halucyjnacji agresora, do obiektu jego pragnienia ${ }^{6}$.

Podstawowym narzędziem propagandy faszystowskiej jest wygłaszane przez wodza przemówienie. Jego zewnętrzna forma pełni funkcję cielesnego pancerza: potwierdza własną solidność (617). „To przemawianie jest dowodem; natomiast sama myśl wyrażona w mowie nie próbuje niczego dowodzić - raczej pozwala czemuś wybrzmieć" - pisze Theweleit (617). Przemówienie faszystowskie, wypowiadane głosem autorytetu, głosem „pana mowy”, stanowi narzędzie kreacji rzeczywistości. Mówienie jest tu płodzeniem (605), i nie jest to metafora przypadkowa: wspólnota słuchająca przemówienia wodza jest w swoim najgłębszym sensie homospołeczna, połączona więzią zakazanej erotyki, w obrębie której kobiecy sposób rodzenia zostaje zastąpiony męskim.

Kiedy wódz przemawia, a wokół formuje się grupa słuchaczy, wówczas mówca i słuchacz gotowi są na najbardziej zakazane zetknięcie obu stron [...]. Wtedy mężczyźnie [...] wolno nawet płakać [...]. Oto jego orgazm większy przeżyje tylko przy zabijaniu.

Podczas rytuału męsko-męskiego przekonywania, będącego raczej swoistym rodzeniem z głowy, czyli męską formą dziewiczego porodu ${ }^{7}$, aniżeli

6 O halucynacji u źródeł morderstwa pisze Gérard Bonnet w książce Le remords. Psychoanalyse d'un meurtier, Presses Universitaires de France, Paris 2000.

7 Różnicę między kobiecym i męskim rodzeniem możemy wzbogacić o aspekt, o który w czasie konferencji „Polska pamięć" upomniała się dr Katarzyna Bojarska, powołując się na następujący fragment Susan Buck-Morss: „There is another aspect of violence, that of the historical event of insurrection itself. Hegel was quite comfortable thinking human progress and human violence as necessarily correlated. So were, for different reasons, Dessalines, Karl Marx, Frantz Fanon, and Ernest Renan. From the standpoint of universal history, however, the issue is not so clear. To argue that the birth of a new idea of humanity - whether by slave revolution, class revolution, or national liberation - must be bloody, makes a first principle out of violence, a cult of blood-letting that grants too much legitimacy to the masculinist culture of the warrior. Fanon's psychology of violence as a purging of colonial consciousness is compelling in theory, but problematic as a principle of practice. Is the blood that stains the midwife of a different order? Surely, helping to bring life into the world is qualitatively different, from a human point of view, from the blood that stains by taking life away". S. Buck-Morss Universal History Upside-Down. Reflections on Hegel and Haiti: A Response to the Critics, unpublished manuscript (2013). Dziękuję Katarzynie Bojarskiej za udostępnienie mi tego cytatu. 
efektem męskiej miłości, kształtuje się „wyższy poziom” maszyny do zabijania, której celem jest zniszczenie „niższego poziomu” w akcie kopulacji tworzącym państwo. Kto nie płacze, kogo nie uszczęśliwia forma wyłaniająca się z ust wodza, kto zarazem nie dołącza do formacji, jaka w odpowiedzi na jego słowa powstaje po drugiej stronie, tego należy wyrzucić, ten jest inny - to podsłuchiwacz, potencjalny donosiciel (616).

Słuchacz faszystowskiego przemówienia nie jest tylko odbiorcą określonego sensu - tym bardziej że większość tych sensów zazwyczaj dobrze zna i afirmuje - ale

zostaje dopuszczony do procesu produkcji, który odczuwa teraz jako własny. Kontakt z formą, jaką tworzy mowa, czyni zeń aktora. Odtąd jest już czymś więcej niż tylko opiłkiem żelaza w polu magnetycznym - zajmuje własne miejsce w obrębie samego modelu, sam przyłącza się do całości i zachęca sąsiada: towarzyszu, musimy stać razem! (619)

W obrębie faszystowskiej wspólnoty stale zachodzą dwa ruchy: łączenie w hierarchiczną strukturę tych, którzy zostali uznani za godnych zjednoczenia, i eliminacja wszystkich tych, których przyłączyć nie można. Dlatego też Jean Pierre Faye określił mowę totalitarną mianem ,języka aborcyjnego": owi „wszyscy”, w których imieniu mówi wódz, to zaledwie niektórzy, ci uznani za posiadaczy „niemieckiej duszy”. „Jedność narodu” sprowadza się tu zawsze do udręczonego ciała mężczyzny-żołnierza po ciężkich walkach toczonych na wszystkich frontach stłumienia (578). Przemoc, uważa Theweleit, stanowi substytut nieudanych aktów seksualnych i odebranej nadziei na socjalizację.

Wygrana na tym froncie wytwarza charakterystyczne moralne odrętwienie. Wrażliwość zostaje zamrożona i odcięta. Jak w klasycznym studium W.R. Biona On arrogance, zdominowana przez popęd śmierci troska o siebie zmienia się w arogancję̧. Empatia, odczucia związane z bólem, lękiem i wzajemną troską to zbyt duże ryzyko dla pancerza, za którym, zdaniem Theweleita, skrywają się chłopcy zbyt wcześnie zabrani matkom.

„Mężczyźni ci czują się tym bezpieczniej, im bardziej rzeczywistość jawi się im jako martwa, uporządkowana, monumentalna" (222). W świetle

8 J.P. Faye Théorie du récit. Introduction aux "langage totalitaires", Hermann, Paris 1972, cyt. za: MF, s. 616.

9 W.R. Bion On arrogance, "The Psychoanalytic Quarterly” 2013 [1958] vol. LXXXII no. 2. 
rozważań Theweleita właściwy totalitaryzmom monumentalizm można zrozumieć jako "mechanizm obrony przed niepokojącą wielorakością wszystkiego, co żywe”. Rzesze można budować „wyłącznie z i na umarłych” (222), traktując uśmiercone życie jako budulec, którym można dowolnie rozporządzać, budując gmach przyszłości.

\section{Traverso: nadejście pamięci}

Jeśli nawet pod każdą szerokością geograficzną władza zmusza ludzi, by zasiedlali podsuwaną im propagandową wizję, to poszczególne jej wersje różnią się między sobą w sposób zasadniczy. Różnią się między innymi tym, czy „uwzględniają więcej czy mniej wzajemnie kontrolujących się podmiotów i czy podmioty te są obywatelami"10. Istnieje zasadnicza różnica między historią Rwandy przed ludobójstwem i po nim, historią Wielkiej Brytanii przed Erikiem Hobsbawmem i po nim, historią Francji przed Michelem Foucaultem i po nim, a także historią Polski przed Janem Tomaszem Grossem i po nim. „Książka Grossa - napisał Przemysław Czapliński o Sąsiadach - uniemożliwiła kontynuację tej autoerotycznej żałoby, jaką literatura polska odprawiała nad zgładzoną społecznością żydowską"11.

Enzo Traverso uważa, że na modyfikację sposobu myślenia i pisania o historii XX wieku najsilniej wpłynął przełom roku 1989. Wśród spowodowanych przezeń zmian Traverso wymienia pojawienie się pamięci: „zakrzepły czas zimnej wojny ustąpił i mogło się odsłonić mnóstwo wspomnień do tej pory ocenzurowanych, utajnionych lub stłumionych"12. Z równą intensywnością rozpoczął się jednak wówczas proces odwrotny: zamarzania, zastygania, zapadania się pojęć, które nagle utraciły znaczenie. Tak właśnie „umieszczona w nowym paradygmacie pamięć zepchnęła na drugi plan pojęcie społeczeństwa, które od lat 6o. do końca 8o. zdawało się niepodzielnie panować

10 Ph. Gourievitch We Wish to Inform you that Tomorrow We Will Be Killed with Our Families. Stories from Rwanda, Picador, New York 1999, s. 181.

11 "Sąsiedzi jawią się jak zabójcza parafraza literatury małych ojczyzn - jej śmiertelnie poważny pastisz. [...] po publikacji Sq̨siadów polska literatura małych ojczyzn w jedną noc posiwiała", P. Czapliński Prześladowcy, pomocnicy, świadkowie. Zagłada i polska literatura późnej nowoczesności, w: Zagłada. Współczesne problemy rozumienia i przedstawiania, red. P. Czapliński, E. Domańska, Wydawnictwo „Poznańskie Studia Polonistyczne”, Poznań 2009, s. 164. 
w gabinetach historyków"13. Książka Traverso Historia jako pole bitwy jest sugestywną opowieścią o konsekwencjach tego zdarzenia, które przechwytując emancypacyjną energię małych opowieści, stłumiło wiele opowieści większych, a na kolejne podmioty sprowadziło damnatio memoriae.

Istnieje zasadnicza różnica pomiędzy „zwrotem pamięciowym” na wschodzie i na zachodzie Europy, zauważa Traverso. W Europie Wschodniej do przeszłości powraca się prawie wyłącznie pod sztandarem nacjonalizmu. Przywołuje przykład polskiego Instytutu Pamięci Narodowej, którego celem od roku 1998 jest ochrona pamięci „zbrodni komunistycznych i nazistowskich popełnionych w okresie od 1 września 1939 do 31 grudnia 1989"14. Historię XX wieku celebruje się tu, twierdzi Traverso, ,jako długą noc totalitarną i jedno wielkie męczeństwo narodowe", co stanowi przeszkodę w wypracowywaniu krytycznego spojrzenia na przeszłość.

Podobna wizja przyświeca historii narodowej inspirowanej przez budapesztański Dom Terroru czy niektóre ustawy przyjęte przez Parlament Ukrainy $^{15}$.

Przedstawiając same siebie jako „ofiary”, narody Europy Wschodniej pozostawiają niewiele miejsca na upamiętnianie Holokaustu. Tutaj pamięć Szoah nie odgrywa tej samej wspólnotowej roli, co na Zachodzie. Jest ona postrzegana jako swojego rodzaju pamięć konkurencyjna, jako przeszkoda do pełnego uznania cierpień doznanych przez różne inne wspólnoty narodowe w XX wieku. Ten kontrast jest paradoksalny, ponieważ Europa Wschodnia była miejscem ludobójstwa popełnionego na Żydach: to właśnie tu żyła ogromna większość ofiar Szoah, i właśnie tu nazizm stworzył getta, następnie rozpoczął masakry, wraz z początkiem wojny przeciw ZSRR, a w końcu umiejscowił obozy zagłady. ${ }^{16}$

Szokującą, bo rozgrywającą się na lewicy egzemplifikacją rywalizacji produkowanej przez formułę nacjonalistycznej pamięci stała się ostatnio dyskusja na łamach „Krytyki Politycznej”. Rozpoczęła ją Irena Grudzińska-Gross, która w recenzji książki Marcina Napiórkowskiego Powstanie

14 Tamże, s. 315.

15 Tamże, s. 316.

16 Tamże. 
umartych. Historia pamięci 1944-2014 zapytała autora „A gdzie są Żydzi?”. Zdziwiło ją bowiem, że „jest możliwe napisanie w roku 2016 ponad 430-stronicowej książki o pamięci o wojennej Warszawie bez obecności Żydów”"17. Książki erudycyjnej, przywołującej Waltera Benjamina, ale pamięć Zagłady traktującej w kategoriach studiów etnicznych. Książki poświęconej pamięci wojennej Warszawy, w której nie znalazło się miejsce na trzysta tysięcy jej mieszkańców.

W odpowiedzi Grudzińskiej-Gross głos zabrał Bartłomiej Sienkiewicz, były minister spraw wewnętrznych. Z miejsca zarzucił on pytającej wspomnianą przez Traverso rywalizację cierpienia. „Ścigając się na pamięć o ofiarach, tylko wzmacniamy swoje traumy", ostrzegał ${ }^{18}$. Jeszcze smutniejsze wrażenie pozostawił tekst Marcina Napiórkowskiego, zatytułowany Czy wolno napisać książkę, która nie jest o Żydach? ${ }^{19}$

Ponieważ Marcin Napiórkowski przedstawia się jako semiotyk, nie mogę nie podsunąć mu pod rozwagę następującego cytatu: „zgodnie z fundamentalnym założeniem strukturalizmu, znaczenie tkwi w sposobie, w jaki obiekty semiotyczne są wobec siebie systematycznie sytuowane"20.

Dramat tej dyskusji polega na tym, że adwersarze Ireny Grudzińskiej-Gross nie są ani narodowcami, ani negacjonistami i ani im w głowie kwestionować cierpienia Żydów. Powtarzając endecki gest wykluczenia, uważają jednak, że są to cierpienia etniczne, nie obywatelskie, ani też narodowe polskie $^{21}$. Tak właśnie powstaje niepojęta dla zachodnich Europejczyków rywalizacja cierpień, której dziwił się Enzo Traverso.

17 http://www.krytykapolityczna.pl/artykuly/historia/20160909/grudzinska-gross-powrot-niepamieci (14.10.2016).

18 http://www.krytykapolityczna.pl/artykuly/historia/20160914/sienkiewicz-jak-emancypowac-zombie (14.10.2016).

http://www.krytykapolityczna.pl/artykuly/historia/20160912/czy-wolno-napisac-ksiazkektora-nie-jest-o-zydach-polemika (14.10.2016). Notabene jako autorka studium o żydowskich wątkach u Gustawa Herlinga-Grudzińskiego [https://ispan.waw.pl/journals/index.php/slh/article/download/slh.2015.014/1627 (14.10.2016)]] na Festiwalu Schulzowskim w roku 2014 uczestniczyłam w dyskusji o trudności godzenia statusu pisarza polskiego z tożsamością żydowską Herlinga. Tytuł naszego panelu odwracał ten problem zupełnie jak tytuł Napiórkowskiego i brzmiał "Czy istnieje obowiązek bycia pisarzem żydowskim?". E. Zerubavel Time Maps. Collective Memory and the Social Shape of the Past, The University of Chicago Press, Chicago-London 2003, s. 7. 


\section{Jameson: historią jest to, co boli}

Istnieje definicja historii, która korygując te i inne nadużycia pamięci, mogłaby przywracać ją społeczeństwu, zarazem ryglując powrót niebezpiecznych utopii. Pochodzi ona z książki Frederica Jamesona The Political Unconscious. Narrative as a Socially Symbolic Act:

History is what hurts, it is what refuses desire and sets inexorable limits to individual as well as collective praxis, which its „ruses" turn into grisly and ironic reversals of their overt intention. ${ }^{22}$

\section{Propozycja przekładu:}

Historia jest tym, co boli, co stawia opór pragnieniu i wytycza nieprzekraczalne granice dla działań indywidualnych i zbiorowych, a poprzez swoje „pułapki” ukazuje ponury i ironiczny rewers intencji, które im przyświecały".

W takiej definicji historii krytycznej spotykamy - jako jej antytezę - pamięć pragnienia, która nie chce przyjąć do wiadomości wytyczonych mu/ jej granic. Konfrontowani z nią w Polsce roku 2016 bierzemy ją za zjawisko nowe, podczas gdy Jameson już w roku 1981 denuncjował ją jako złudzenie amerykańskiej lewicy.

Także Paul Ricoeur, niemający zapewne tylko lewicy na myśli, pisał o tej pamięci w Pamięci, historii, zapomnieniu. Nazwał ją pamięcią-powtórzeniem, pamięcią zmanipulowaną, jak ta z eseju Wyki.

Narracja jako środek [służący przeprowadzeniu remontu historii, dlatego zawsze] staje się [...] pułapką, gdyż wyższe moce przejmują jej kompozycję fabularną i narzucają kanoniczną narrację poprzez zastraszenie, uwiedzenie, strach lub pochlebstwo. Działa tutaj chytra forma zapomnienia, wynikająca $\mathrm{z}$ pozbawienia podmiotów działania społecznego ich pierwotnej zdolności opowiadania o sobie samych. To pozbawienie jednak nie dokonuje się bez potajemnego współudziału, za którego sprawą zapomnienie staje się na poły biernym, na poły czynnym zachowaniem, co widać w przypadku zapominania przez unika-

22 F. Jameson The Political Unconscious. Narrative as a Socially Symbolic Act, Methuen et Co, New York 1981, s. 88. 
nie, będącym wyrazem złej wiary, i związanej z nią strategii unikania, motywowanej przez niejasną wolę niedowiadywania się, nieprzeprowadzania przez środowisko obywatelskie śledztwa w sprawie doznanej [częściej: zadanej] krzywdy, słowem przez pragnienie pozostawania w niewiedzy. ${ }^{23}$

\section{Pamięć nieumarła na przykładzie pamięci pogromu kieleckiego}

Szczególna odmiana owej Ricoeurowskej pamięci-powtórzenia dochodzi dziś do głosu w Polsce ogarniętej memorialnym szałem, wyprodukowanym przez politykę historyczną dwóch ostatnich dekad. Przez aluzję do tekstu Jeremy'ego Cohena Undead. A Zombi Oriented Ontology ${ }^{24}$ można ją nazwać pamięcią nieumarłą. Wprowadza ona korektę do optymistycznych Ricoeurowskich klasyfikacji, rozrywając triadę: pamięć zablokowana - pamięć powtórzenia - pamięć zobowiązana. Udowadnia też, co mogłoby zainteresować Dominicka LaCapręę, że wybudowanie nagrobka nie tylko nie uspokaja, ale wręcz aktywizuje niektóre typy pamięci.

Undead, ów rzeczownik skrajnie zaprzeczony, desygnuje negatywność, która „nie jest ani żywa, ani też nie ma udziału w spoczynku śmierci”26. Odrywa się ona od rzeczywistości i czasu, bo służy innym celom niż poznawcze i żałobne. Dlatego też, mimo wielokrotnego czasem pochówku, nie może przejść w stan, który Paul Ricoeur nazywa fortunnym zapomnieniem ${ }^{27}$. Pamięć ta znajduje się w metastazie, bez perspektyw terminacji, i właśnie dlatego można ją porównać do fenomenu undead. Jako produkt nieustannego czuwania stanowi aberrację, którą Fryderyk Nietzsche krytykował w Pożyteczności i szkodliwości historii dla życia ${ }^{28}$.

P. Ricoeur Pamięć, historia, zapomnienie, przeł. J. Margański, Universitas, Kraków 2014, s. XX.

J.J. Cohen Undead. A Zombi Oriented Ontology , IJ Journal of Fantastic in the Arts" 2012 vol. 23 no. 3 , S. 393-412.

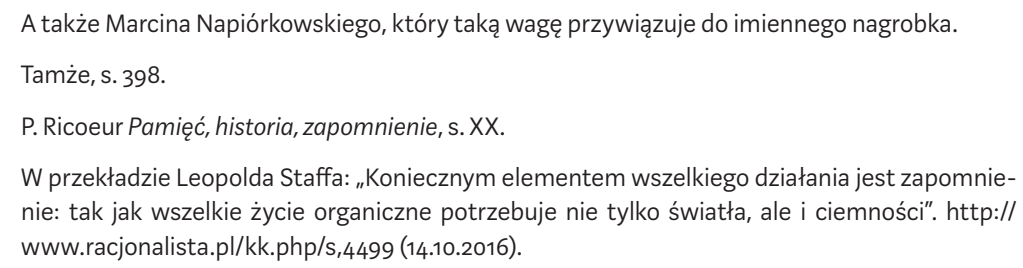
nie: tak jak wszelkie życie organiczne potrzebuje nie tylko światła, ale i ciemności". http:// www.racjonalista.pl/kk.php/s,4499 (14.10.2016). 
Z tą odmianą pamięci zetknęłam się, pracując nad książką Społeczny portret pogromu kieleckiego ${ }^{29}$. Studium to jest szczegółową analizą karier funkcjonariuszy WUBP i MO, a także genealogii kieleckich pogromszczyków, ich sytuacji rodzinnej, stanu majątkowego, przynależności organizacyjnej, losów wojennych i powojennych. Za Robertą Senechal de la Roche ${ }^{30}$ przyjmuję koncepcję pogromu jako formy samopomocy społecznej, której udziela sobie społeczeństwo zawiedzione przez państwo w oczekiwaniach, że położy ono kres „panoszeniu się" żydowskich dewiantów. Można powiedzieć, że za pomocą pogromu kieleckiego to „panoszenie się" zostało powstrzymane i sprowadzone do formy 42 trupów ${ }^{31}$.

Wyliczę najważniejsze reguły pamięci zaobserwowane przeze mnie w toku kwerendy i prac nad książką.

1. Pamiętanie (przypominanie sobie = hypomnesis) ma swoją ekonomię, zmienną i nielinearną u różnych aktorów.

2. Pamiętanie jest zależne od sprawstwa (agency) poszczególnych osób i instytucji. Oznacza to, że inna jest pamięć sprawców i ofiar. Ci pierwsi, po osiągnięciu rozładowania w przemocy, rozluźniają się i stopniowo nabierają dystansu do zdarzenia, którego szczegóły łatwo zacierają się im w pamięci. Drudzy tkwią w przymusie powtarzania i/lub wpadają w zrytualizowany lament ${ }^{32}$.

3. Inny proces zachodzi na poziomie zbiorowym, gdzie w ciągu dekad dzielących dwa pogromy kieleckie, ten z roku $1918^{33}$ i ten z roku 1946,

29 Dwa tomy (narracja i zbiór źródeł) pod tym tytułem ukażą się w roku 2017 w Wydawnictwie Czarna Owca.

30 R. Senechal de la Roche, Collective Violence as Social Control, "Sociological Forum” 1996 vol. 11 no. 1, s. $87-128$. Naśladuję tu sformułowanie Klausa Theweleita, Męskie fantazje, s. 95.

S.J. Tambiah Levelling Crowds. Ethnonationalist Conflicts and Collective Violence in South Asia, University of California Press, Berkley - Los Angeles - London 1996, s. 194.

33 Do pierwszego pogromu Żydów w Kielcach doszło 11 listopada 1918 roku. Wiec, na którym kieleccy Żydzi mieli wybrać posłów do krajowego samorządu żydowskiego, zorganizowano w Teatrze Polskim w Kielcach. Spotkanie rozpoczęto od modlitwy dziękczynnej za odzyskanie niepodległości. Gdy przemówił mecenas Frajzynger, który nie znał jidysz, a sala domagała się, by mówił w tym języku, w miasto poszła wiadomość, że „Żydzi nie chcą Polski”. Puszczono pogłoskę, że przed teatrem został zraniony polski legionista. Gdy do środka wtargnął tłum, w bijatyce zginął siedemnastoletni skaut, Chaim Jeger. Przed teatrem zamordowano Szmula Owsianego. Na mieście tłum rabował żydowskie sklepy i wybijał okna. W pogromie zginęło czterech Żydów, a stu zostało rannych. Władze polskie nie kwapiły się z wyjaśnianiem okolicz- 
można zobserwować zdumiewające podobieństwa zarówno w przebiegu przemocy, jak i w schemacie postępowania z tym zdarzeniem. W obu przypadkach jednym z czynników galwanizujących trwający już pogrom była pogłoska o śmierci polskiego oficera ${ }^{34}$. W obu też przemoc wybuchła po odebraniu Żydom bronii3 ${ }^{35}$. Kolejną kłopotliwą idiosynkrazją jest fakt, że po stronie sprawców i ofiar brały w niej udział osoby o podobnych nazwiskach (np. Grynbaum, Furman).

4. Mimo pozornego wygaśnięcia, pod wpływem czynników społecznych (propaganda, autorytety) nawet pamięć na pozór dobrze przepracowana może ulegać wzbudzeniu i regresowi. Pojawia się wówczas coś, co Kurt Theweleit nazywa wyuczonym wyparciem: versierten Verleugnung - wyparciem, o którym podmioty wiedzą, że ukrywa prawdziwy przebieg zbrodni ${ }^{36}$. Jest ono strukturalnie identyczne z zasilanym propagandą procesem produkcji pamięci nieumarłej.

Gdyby w sposób schematyczny podzielić kielecką pamięć po pogromie, można by wyodrębnić nie tyle pięć faz, ile archipelag swobodnie pływających anachronicznych wysp pamięci, w których mieszają się elementy wyparcia i anamnezy.

1. Okres pierwszy, ścisłej konfiskaty pamięci ${ }^{37}$, rozpoczyna się w roku 1946, zaraz po pierwszym lipcowym procesie i trwa do lat 8o. XX wieku ${ }^{38}$. Rozległe archiwalia kieleckie stają się zupełnie niedostępne dla historyków, publikacje na temat pogromu zostają obłożone nieoficjalnym zakazem, część źródeł ulega zniszczeniu. Uruchamia

ności, dopiero w 1922 roku pięć osób skazano na kilka miesięcy więzienia. Zob. .). Karolczak Koncert na cztery epoki, „Przemiany” 1989 nr 1; M. Maciągowski Przewodnik po żydowskich Kielcach. Śladami cieni, Wydawnictwo Austeria, Kraków-Budapeszt 2008, s. 37; K. Urbański, R. Blumenfeld Słownik historii kieleckich Żydów, Kieleckie Towarzystwo Naukowe, Kielce 1995, S. 105.

Wątek domniemanego „zabicia polskiego oficera” pojawia się też w licznych relacjach dotyczących pogromu kieleckiego 1946 roku.

35 P. Wróbel Listopadowe dni - 1918. Kalendarium narodzin II Rzeczpospolitej, PAX, Warszawa 1988, S. 82.

K. Theweleit Śmiech morderców. Breivik i inni. Psychogram przyjemności zabijania, przeł. P. Stronciwilk, PWN, Warszawa 2026. 
to produkcję scenariuszy spiskowych, w których inicjatywa przypisywana jest kolejno: „andersowcom” (przez władze komunistyczne), władzom komunistycznym (przez „andersowców”), a także sporadycznie syjonistom (na przykład raport biskupa Czesława Kaczmarka, później książka Józefa Orlickiego ${ }^{39}$ ).

2. Po osłabnięciu komunizmu, w latach 8o. pojawia się wyłom w po-

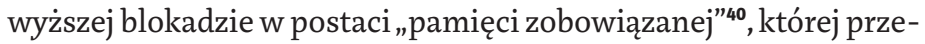
jawy można odnaleźć w filmie Marcela Łozińskiego Świadkowie oraz wybitnym reportażu Jerzego Sławomira Maca Kto to zrobił, opublikowanym w „Kontrastach” (oba z roku 1986). Finałem tego etapu było zakończenie drugiego śledztwa kieleckiego w październiku 2004 roku, kiedy prokurator Krzysztof Falkiewicz z Oddziałowej Komisji Ścigania Zbrodni przeciwko Narodowi Polskiemu w Krakowie ogłosił, że żadna z hipotez spiskowych nie znalazła potwierdzenia ${ }^{41}$.

3. Po roku 1989 pamięć kielecka ulega odblokowaniu i odreagowuje. W materiałach drugiego śledztwa, które toczyło się w latach 1994-2004, zwraca uwagę ogromna liczba plotek i jałowych tropów, obsesja fałszywych wspomnień, zalew przypadków psychotycznych i strach owocujący donosami i anonimami ${ }^{42}$. Wszystkie te sygnały były skrupulatnie sprawdzane najpierw przez prokuratora Zbigniewa Mieleckiego, potem zaś przez jego następców, prowadzących drugie śledztwo kieleckie.

4. Mimo ogłoszenia rezultatów tego śledztwa falsyfikujących hipotezy konspiracyjne nastąpił nawrót pamięci spiskowej, którą można rozumieć jako obronę przed poczuciem winy z fazy nr 2 . Hipotezy

39 J. Orlicki Kulisy i tajemnice pogromu kieleckiego, Temax, Kraków 1992.

Termin Paula Ricoeura.

Wokół pogromu kieleckiego, oprac. J.Żaryn, Ł. Kamiński, t. 1, Instytut Pamięci Narodowej, Warszawa 2006.

Zob. np. list: „4/7/1996 Komisja do Badania Zbrodni Przeciwko Narodowi Polskiemu w Poznaniu. W związku z ogłoszeniem, że bada się obecnie sprawę tzw. pogromu kieleckiego w 1946 roku, proszę o skontaktowanie się z ob. [tu dane kontaktowe], który był tam i prawdopodobnie jako pracownik UB strzelał do Żydów. Wiem to, gdyż chwalił się tym póżniej, opowiadając o tym mojemu ojcu. Mój ojciec już nie żyje, a ja nie znam bliższych szczegółów. Zapamiętałem tylko z opowiadań mojego ojca, że taki fakt miał miejsce. Niestety muszę zachować anonimowość, gdyż chodzi o mojego sąsiada". Akta śledztwa, teczka 6, sygn. Zs.S1/93, k. 1157. Na karcie następnej znajduje się przesłuchanie wskazanego w anonimie mężczyzny, który 1/8/1996 zeznał, że „w Kielcach nigdy nie przebywał, a nawet nie był tam okazyjnie". 
o prowokacji stawały się coraz bardziej popularne od czasu artykułu Krystyny Kersten w „Tygodniku Solidarność” zatytułowanego Kielce, 4 lipca $1946^{43}$, a następnie po publikacji książki Michała Chęcińskiego Poland: Communism. Nationalism. Anti-semitism ${ }^{44}$. Ważną rolę w budowaniu siły tego zjawiska odegrał też pisarz Krzysztof Kąkolewski ${ }^{45}$. W drugim tomie publikacji IPN Wokót pogromu kieleckiego, który ukazał się w roku 2008 pod redakcją Leszka Bukowskiego, Andrzeja Jankowskiego i Jana Żaryna otwarcie powrócił do hipotezy spisku NKWD w pewnym sensie zdystansowano się od rezultatów własnego śledztwa ${ }^{46}$.

5. Etap piąty, dodany tu prognostycznie, to pamięć postspiskowa. Początek takiej krytycznej lokalnej pamięci wiąże się z działalnością Stowarzyszenia im. Jana Karskiego w Kielcach, od ponad dekady kierowanego przez psychologa i działacza społecznego Bogdana Białka ${ }^{47}$.

\section{Przyszłość?}

W tekście $O$ porzadkach historycznych Kazimierz Wyka pisze:

Logika historyczna nie jest logiką natychmiastową. Doświadczenie, aczkolwiek już rozegrane do końca, prawie nigdy za pierwszym swoim wystąpieniem nie wdraża się w umysły tych, dla których było przeznaczone. [...] Logika historii jest raczej logiką nawracającej fali. Po dwakroć, po trzykroć uderzyć musi w to samo miejsce, zanim się cofnie i uniesie z sobą wniosek. ${ }^{48}$

K. Kersten Kielce, 4 lipca 1946, „Tygodnik Solidarność” 8 grudnia 1981.

M. Chęciński Poland: Communism, Nationalism, Anti-Semitism, Kerz-Kohl Publishing, New York 1983.

Zob. np. K. Kąkolewski Umarły cmentarz, "Tygodnik Solidarność", nr 51(326), 16. grudnia 1994 i książka pod tym samym tytułem z roku 1996. Krzysztof Kąkolewski trafił na wiele interesujących źródeł, jednak brak kompetencji naukowych nie pozwolił mu przeprowadzić ich krytyki i w rezultacie napisał dosyć słabą książkę.

Wokół pogromu kieleckiego, red. J. Żaryn, L. Bukowski, A. Jankowski, t. 2, Instytut Pamięci Narodowej, Warszawa 2008.

Zob. portret Andrzeja Białka w filmie Michała Jaskulskiego Planty 7/9 (2016).

K. Wyka Życie na niby, Universitas, Kraków 2010, s. 197-198. 
Kieleccy Żydzi dwukrotnie odczuli na sobie logikę „powracającej fali”, wciąż jednak nie jest jasne, jaki wniosek unieśli z sobą kielczanie. Dziś nie ma już Żydów w mieście, ale na froncie walki o pamięć nie ma to przecież żadnego znaczenia. Najnowszym zdarzeniem na tym froncie jest apel o wznowienie śledztwa w sprawie pogromu kieleckiego, który wpłynął ostatnio do kieleckiego Oddziału IPN ${ }^{49}$. Sygnatariusze, wśród których jest ONR, stowarzyszenie Brygady Świętokrzyskiej NSZ i krewna Mariana Sołtysiaka, dowódcy oddziału Wybranieckich, na którym spoczywa odium zbrodni na Żydach ${ }^{50}$, upominają się o oczyszczenie „dobrego imienia" kielczan z zarzutu antysemityzmu.

Zobaczymy, jaką rolę w tej rywalizacji odegra sztuka. W bieżącym sezonie (luty 2017) Teatr im. Stefana Żeromskiego w Kielcach zamierza wystawić dramat Tomasza Śpiewaka Kielce to nie Dallas, dotyczący pogromu kieleckiego. Reżyserować będzie Remigiusz Brzyk, uczeń Krystiana Lupy.

49 https://ekai.pl/diecezje/kielecka/x104220/kielce-apel-o-wznowienie-sledztwa-w-sprawiepogromu/ (14.10.2016). Sygnatariusze apelu: Małgorzata Sołtysiak - wiceprezes Stowarzyszenia Ruch Społeczny im. Lecha Kaczyńskiego w Kielcach, Wojciech Zapała - prezes Grupy Rekonstrukcji Historycznej im. por. Stanisława Grabdy ps. „Bem”, Michał Sadko - prezes Zarządu Fundacji „Odzyskajmy Naszą Historię", Karolina Lebiedowicz - sekretarz Okręgu Świętokrzyskiego Narodowych Sił Zbrojnych, Karol Michalski - prezes Stowarzyszenia "Kieleccy Patrioci” oraz Filip Bator - sekretarz Brygady Świętokrzyskiej Obozu Narodowo-Radykalnego.

Zob. A. Skibińska, J. Tokarska-Bakir Barabasz iŻydzi.Z historii oddziału AK „Wybranieccy”, w: tejże Okrzyki pogromowe. Szkice z antropologii historycznej Polski 1939-1946, Wydawnictwo Czarne, Wołowiec 2012, s. 170-219. Zob. też https://www.holocaustresearch.pl/index.php?mod=new$\mathrm{S} \&$ show=310\&template=print $(10.01 .2017)$. 


\section{Abstract}

\section{Joanna Tokarska-Bakir}

THE INSTITUTE OF SLAVIC STUDIES, POLISH ACADEMY OF SCIENCES

Undead Memory: Reading Kazimierz Wyka in Poland in 2016

In Western Europe, memory studies are marked by an effort to give voice to those silenced by dominant narratives. In Poland, meanwhile, the current 'memory turn' openly flirts with post-truth and paves the way for a new hegemony. This way of framing memory takes advantage of the poststructuralist humanities' defenceless position, and it gradually appropriates its tools and yokes them to the rhetoric of propaganda. The new project of collective memory breaks with Ricœur's triad of blocked memory - memory of repetition - obligated memory. It privileges blockage and repetition as modes of commemorating ('undead memory' - a paradoxical posthumanist realization of the category of the undead). Tokarska-Bakir demonstrates this tendency in a case study on the development of public discourse on the Kielce pogrom of 1946.

\section{Keywords}

undead, memory propaganda, fascist culture, Jameson's critical history, manipulated memory, memory of the Kielce pogrom of 4 July 1946 